\title{
Multiorgan ECV as measured by EQ-MRI in systemic amyloidosis
}

\author{
Sanjay M Banypersad ${ }^{1,2^{*}}$, Steve Bandula ${ }^{3}$, Daniel Sado ${ }^{1}$, Jennifer H Pinney ${ }^{2}$, Simon D Gibbs ${ }^{2}$, Viviana Maestrini ${ }^{1}$, \\ Marianna Fontana ${ }^{1,2}$, Steven K White ${ }^{1}$, Shonit Punwani ${ }^{3}$, Stuart Taylor ${ }^{3}$, Philip N Hawkins ${ }^{2}$, James Moon ${ }^{1}$ \\ From 16th Annual SCMR Scientific Sessions \\ San Francisco, CA, USA. 31 January - 3 February 2013
}

\section{Background}

Systemic AL Amyloidosis causes multiorgan dysfunction through interstitial expansion. We measured the extracellular volume fraction (ECV) in the : heart, liver, spleen and skeletal muscle in healthy volunteers and patients with Systemic Amyloidosis to test the hypotheses that (1) tissue $\mathrm{ECV}$ is greater in systemic AL Amyloidosis than in health and (2) ECV tracks organ amyloid burden.

\section{Methods}

Healthy volunteers ( $\mathrm{n}=70 ; 35$ male; 35 female; median age 46 years) and patients with systemic AL Amyloidosis ( $\mathrm{n}=56$; 36 male; 20 female; median age 62 years), with clinical indications for CMR scanning, additionally underwent multi-organ ECV measurement. Technical details were: gadoteric acid, $0.1 \mathrm{mmol} / \mathrm{Kg}$ plus infusion, multibreathhold T1 measurement and equilibrium imaging of heart, liver spleen and biceps muscle at 1.5T (Siemens Avanto). Amyloidosis patients also underwent serum amyloid $\mathrm{P}$ component (SAP) scintigraphy to score liver and spleen involvement by amyloid.

\section{Results}

ECV of the heart, liver, spleen and muscle was significantly elevated in patients with amyloidosis $(0.40,0.33$, 0.42 and 0.12 respectively) compared to healthy controls $(0.25,0.30,0.34$ and 0.09 respectively) $(\mathrm{P}<0.001)$. ECV measured in the liver and spleen tracked increasing organ amyloid burden assessed by SAP scintigraphy $(\mathrm{P}<0.001)$. In healthy volunteers, ECV varied between different organs, being highest in the spleen and lowest in skeletal muscle.

\section{Conclusions}

The cardiac ECV technique measures cardiac amyloid burden, but can be translated into also in other tissues and organs in the body. Here its use is validated against the gold standard of SAP scanning in the liver and spleen. ECV measurement may represent a key technique for measuring ECV increase in systemic diseases.

\section{Funding}

We receive money from Glaxo Smith Kline for some of our studies.

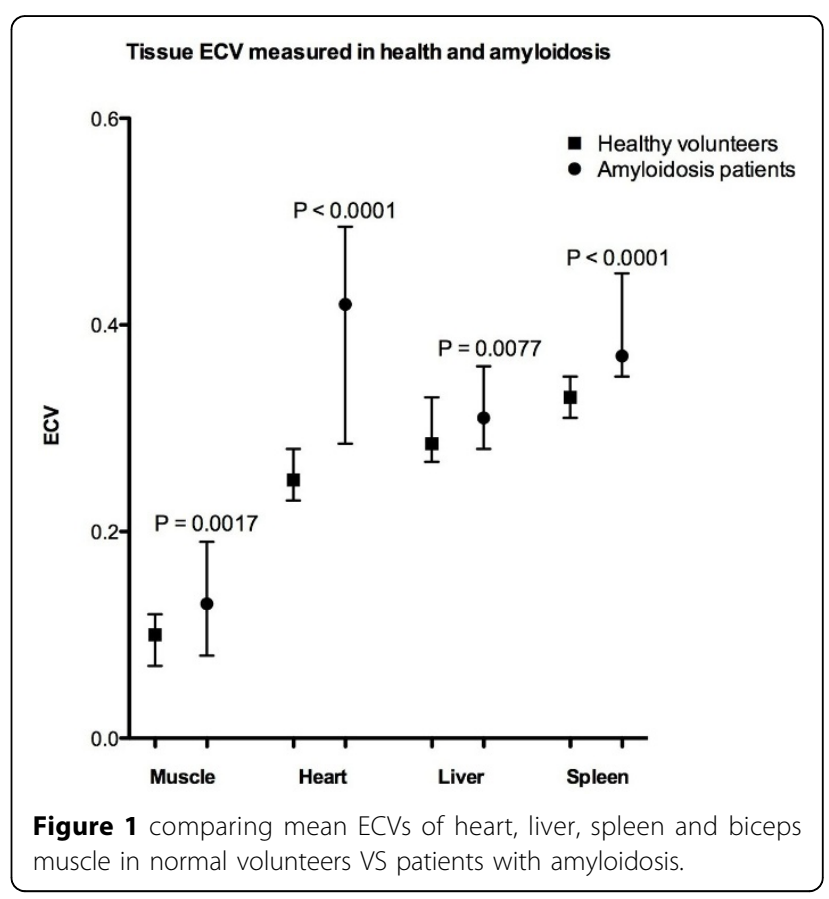

${ }^{1} M R I$, The Heart Hospital, London, UK

Full list of author information is available at the end of the article

(c) 2013 Banypersad et al; licensee BioMed Central Ltd. This is an Open Access article distributed under the terms of the Creative 
Liver

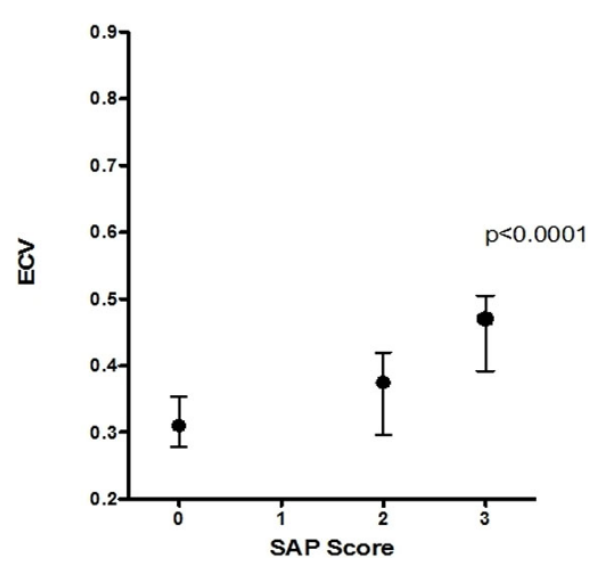

Spleen

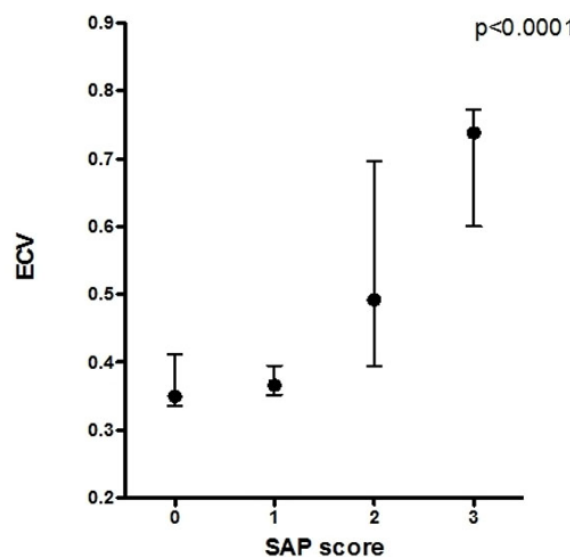

Figure 2 showing ECV tracking amyloid burden when compared to SAP imaging score for liver (left) and spleen (right).

\section{Author details}

${ }^{1}$ MRI, The Heart Hospital, London, UK. ${ }^{2}$ National Amyloidosis Centre, Royal

Free Hospital, London, UK. ${ }^{3}$ Radiology, University College Hospital,

London, UK.

Published: 30 January 2013

doi:10.1186/1532-429X-15-S1-034

Cite this article as: Banypersad et al:: Multiorgan ECV as measured by

EQ-MRI in systemic amyloidosis. Journal of Cardiovascular Magnetic

Resonance 2013 15(Suppl 1):O34.

Submit your next manuscript to BioMed Central and take full advantage of:

- Convenient online submission

- Thorough peer review

- No space constraints or color figure charges

- Immediate publication on acceptance

- Inclusion in PubMed, CAS, Scopus and Google Scholar

- Research which is freely available for redistribution

Submit your manuscript at www.biomedcentral.com/submit 